\title{
STATEMENT TO MEMBERS OF THE COMMONWEALTH MINISTERIAL GROUP
}

Felix Anthony

\section{Introduction}

The Fiji Trades Union Congress, through the Commonwealth Trade Union Council, submits the following statement for urgent consideration by the Commonwealth Ministerial Action Group meeting on Fiji.

We welcome the CMAG meeting. It demonstrates the level of concern shown by the commonwealth at the unlawful and unconstitutional overthrow of the democratically elected People's Coalition government.

The People's Coalition government is a coalition of the Fiji Labour Party, the Fijian Association Party, the VLV and the Party of National Unity. In the first election held following the overwhelming acceptance of Fiji's new constitution, the People's Coalition won 55 seats in Fiji's Parliament. Within the Coalition, the Fiji Labour Party was the largest grouping with 37 members.

The FTUC has close links with the Fiji Labour Party and several of our former leaders are now a part of the Cabinet. Clearly, the People's Coalition has a massive mandate given to it in May 1999. Such a decisive mandate had not been given to any elected government since Fiji's independence in 1970. We, the workers of this country of all ethnic groups, are proud partners in Fiji's governance through the Fiji Labour Party. The People's Coalition was speedily delivering on its program of 
government. It is this success that most explains the actions of terrorists and others supporting them.

\section{Background}

(i) The key demands of the terrorists led by Speight were

- the dismissal of the Prime Minister and the elected government;

- dismissal of the President;

- the abrogation of the Constitution;

- amnesty for Speight and other terrorists;

- the establishment of ethnic Fijian domination through a new constitution;

- and the appointment of a new exclusively ethnic Fijian Government until a new constitution is approved.

Speight has persistently insisted the release of the hostages was conditional on these demands being met - restating them only this evening (5 June).

The narrative below shows most of these demands have already been met. It shows the military's complicity with Speight's cause.

(ii) Following the takeover of Parliament and the taking of hostages including the Prime Minister and members of his Cabinet, the FTUC pledged its support to the President in his decision to assume executive authority and to declare a state of emergency. This course of action appeared logical given that the state of emergency was constitutionally declared.

(iii) However, on Saturday 27 May, following resolutions of the Bose Levu Vakaturaga (Council of Chiefs), the President went beyond this and dismissed the Prime Minister and Cabinet and suspended the Parliament. This effectively was giving in to the first of the demands of Speight and his supporters - i.e. the removal of the People's coalition government.

(iv) The dismissal of the Prime Minister by the President followed resolutions passed by the Bose Levu Vakaturaga (Council of Chiefs). The 
BLV has no constitutional functions with respect to dismissal or appointment of government. It has an advisory role to play in constitutional matters. With respect to the Constitution itself, the BLV had given its unanimous endorsement to the Constitution in early 1997.

(v) Following the takeover of Parliament, supporters of the terrorists plunged the country into orchestrated human rights abuses targeting innocent people and whole communities - especially Indo-Fijians. Workers and farmers have borne the brunt of this violence and human rights abuses. Reports on human rights abuses have been now relayed to the Secretary General separately. The links between terrorists, security forces and vigilante groups have been well documented.

(vi) The military intervention was aimed at restoring law and order. But following the declaration of martial law, the military abrogated the 1997 Constitution. By abrogating the Constitution, the military gave in to two other principal demands of Speight and co-conspirators, i.e., the removal of the President and the abrogation of the Constitution.

The military's action in assuming executive authority itself and abrogating the constitution is totally unnecessary. Further, it has offered an amnesty to the terrorists and engaged in negotiations with them about the framework for a new constitution - two of the other demands of the terrorists.

It is clear that the military has a political agenda that goes well beyond its objective of restoring law and order. It has obvious sympathies with Speight and his group. It has committed itself to preparing a constitution that will enshrine indigenous Fijian domination. It has agreed to a course of action that will allow Speight and his men to be a part of government in the near future.

The military's abrogation of the Constitution has no support in Fiji society. It is condemned by the Fiji Trades Union Congress, the People's Coalition government, by the Fiji Law Society, by the Vice President of Fiji and many chiefs throughout the country, by a whole range of civil society organisations. It has no legitimacy therefore. 
(vii)The sequence of actions taken by the President, the BLV and the Fiji Military Forces have not been directed at solving the hostage crisis, upholding the constitution, and restoring the democratically elected government. On the contrary, they further the principal demands of the terrorists, which were aimed at unlawfully overthrowing a democratic government and the Constitution.

\section{Fiji Trades Union Congress Position}

i) We remind the CMAG and the international community that workers and Fiji's civil society cherish their Constitution. The Constitution is deeply committed to the principles of equality, non-discrimination, human rights, and social and economic rights. It protects and enhances core labour rights. At the heart is the comprehensive Bill of Rights, including its unparalleled provisions on racial discrimination and equality.

ii) The Constitution is the product of five years of consensus building. The specific content is the product of negotiations between all political parties. Both houses of Fiji's Parliament and the Council of Chiefs unanimously approved the Constitution. But even more importantly, a large segment of Fiji society, its non-governmental organisations, trade unions and civic groups directly participated in the constitution-building process. They all have a special sense of ownership over this Constitution.

iii) A key objective of the Constitution was its commitment to protecting and enhancing the rights and interests of the indigenous community. Firm constitutional provisions were made for affirmative action to reduce ethnic disparities.

iv) The Council of Chiefs was given constitutional recognition and granted the sole constitutional authority to appoint the President. The Council of Chiefs' nominees in the senate were given an absolute constitutional veto on matters affecting indigenous Fijian rights and interests, including land matters. Fiji's Constitution is hailed internationally as an exemplary model for the protection and advancement of indigenous rights. 
The abrogation of the Constitution means that there is now an illegal and unconstitutional overthrow of democratic and constitutional government. Any international support for the recent (or future) actions of the Fiji Military Forces would legitimise the overthrow of democracy and constitutional government. It would give recognition to an unlawful and unconstitutional regime.

The overthrow of a constitutional and democratically elected government by the military (through the support of a terrorist group using hostages) offends core civil and political rights reflected in the Harare Declaration.

It is crucial that the integrity of the Commonwealth's commitment to democracy, good governance, human rights and the rule of law are vigilantly defended. The Harare Commonwealth Declaration now stands fundamentally violated in the Fiji Islands. The situation demands an urgent response by the CMAG.

v) Fiji now stares at a total breakdown of law and order, a degeneration into institutionalised racial discrimination, ethnic persecution and serious human rights violations by both the security forces and armed vigilante groups, victimisation and harassment of government members and trade unions, and the Indo-Fijian community in general. Fiji faces the prospect of hostile provincialism. The western provinces which strongly support the elected People's Coalition government are now proceeding with the setting up of an independent state and government.

vi) We are also witnessing a rapid decline in the integrity of Fiji's judiciary, public service and accountability institutions. Fiji's independent Public Service Commission has now been terminated; several judges have already resigned. The public service is being rapidly radicalised as is reflected through the most recent appointments to Fiji's missions abroad.

vii) Workers in Fiji ask that the CMAG give a clear and decisive commitment to helping secure a satisfactory outcome of the crisis, consistent with Fiji's Constitution and the Harare Principles. 
viii)Specifically, we ask that the CMAG take firm and decisive steps to help restore the constitutional and democratically elected government and uphold our Constitution.

We therefore look to the CMAG to take action along the following lines:

ix) Continue to recognise the People's Coalition under the leadership of Prime Minister Mahendra Chaudhry as the legitimate government of the Fiji Islands. This would be consistent with the principles of the Harare Declaration.

Warn the Fiji Military Forces that their failure to restore the democratically elected People's Coalition government and the 1997 Constitution in a reasonable time frame will result in the imposition of the full force of the Commonwealth and international sanctions against the illegal regime set up by the Fiji Military Forces.

Impose an immediate ban on travel to any Commonwealth country:

- of Speight and all members of his interim government,

- all members of the military's Council of Advisers

- heads of public service.

Specify that should the democratically elected government not be restored within two months, the sanctions will include:

i) Fiji's expulsion from the Commonwealth;

ii) A unified suspension of diplomatic relations with the illegal regime set up by the Fiji Military Forces by member states;

iii) Suspension of technical assistance, development aid and other assistance or support by member states and the Commonwealth Secretariat;

iv) Activating a comprehensive trade, sporting, travel, cultural and educational regime of sanctions;

v) Total freeze on all links with Fiji Government, its public service, the military and other institutions; 
vi) A Commonwealth commitment to pursuing further diplomatic, political and economic isolation of the illegal regime through the United Nations and other international agencies;

vii) A commitment to pursuing leaders of any unconstitutional government and Speight and his supporters for human rights abuses under international law, a freezing of their assets in commonwealth countries.

We further ask that the CMAG call for the unconditional and immediate release of hostages.

If the Fiji Military Forces do not restore the elected government and the 1997 Constitution within two months, we ask that the Commonwealth take necessary measures in response, including the setting up and rapid deployment of a stabilising/peacekeeping force.

We stress the need to act now before the situation deteriorates very rapidly.

\section{Conclusion}

Workers, their trade unions and the vast majority or ordinary citizens of Fiji cherish Fiji's membership of the Commonwealth. They look to the commonwealth to take firm and principled action to help restore constitutional government in our beloved country.

We plead that the Commonwealth's actions be decisive so that the armed overthrow of democratically elected governments can be brought to an end. Let there be no mistake about it. The coup underway in the Solomon Islands today (5 June 2000) directly flows from the coup in Fiji.

Terrorists and armed men seem to have the view that the resolve of the commonwealth and the international community will be weak and eventually they will come to terms with a new political order established through the force of guns. 